\title{
Integrated Problem Based Learning for Improvement Soft Skill and High Order Thingking of Vocational Students
}

\author{
S. Hamidah, Yuriani, S. Palupi \\ Department Food and Fashion Education \\ Yogyakarta State University \\ Yogyakarta, Indonesia \\ siti_hamidah@uny.ac.id
}

\begin{abstract}
Education process in university should contribute in a balanced competency mastery between knowledge, skills, and soft skills. The elements of soft skills are crucial in achieving and functionalization of cognitive and psychomotor. Hence, the university as vocational education organizer is responsible for developing the input capabilities of students from various institution including SMK (Vocational High School). This paper describes early study or called preliminary study to develop a model of PBL integrated toward the enhancement of soft skills of high order thinking for vocational students in patisserie expertise. This preliminary study collects early information of patisserie learning in universities and the need of soft skills in various industries in patisserie. This information is important to develop the initial design that describes the integration of PBL with soft skills of high order thinking in patisserie learning, so the role of lecturer and students during the learning process is investigated. This model will contribute to the growth for high order thinking of soft skills in vocational student that is important for success.
\end{abstract}

Keywords-soft skills; patisserie; PBL

\section{INTRODUCTION}

Soft skills are a new way to describe abilities or talents which are visible when people work [James and James in [1]. In the 21 st century, there is a paradigm shift that employees should be more master soft skills than hard skills [Ganzel in [1]. This is in line with the changing paradigm of the knowledge-based economy that requires employees more master soft skills. This skill should be nurtured for a long time, while hard skills can be trained and developed in the workplace. Within the scope of study, soft skills mastery will accompany hard skills mastery. In other words, the hard skills mastery would be good if supported by good soft skills as well.

The soft skills of high order thinking are a form of soft skills that develop strategic thinking, problem solving, creativity, the ability for learning, and work hard to achieve success. High order thinking requires mastering knowledge and solid basic understanding, followed by developing the ability about ways to interpret, analyze, and synthesize knowledge and experiences. Therefore, knowledge will increase and performance skills are better.
Soft skills mastery of high order thinking will give more benefits. This mastery encourages students to develop efforts of skills mastery so they can manage their learning, remembering, and thinking. Moreover, they will learn specific ways different from what is mastered, techniques of thinking to analyze problems and solve it [2].

Learning by Problem-Based Learning (PBL) approach has been done in vocational education, including for patisserie student in some universities. Learning by this approach, intend to improve the professionalism of graduates. Furthermore, it is also as a response toward the emergence of learning paradigm in 21 st century as proposed Jeffries in [3] from the paradigm of teacher-directed and traditional lecture format to a paradigm of self-directed learning, interactive learning.

Vocational education in teacher college (LPTK) was held to prepare academic staffs who will teach in vocational schools. Graduates should be able to manage problem-based learning. This is partly related to requirement of curriculum 2013 implementation or national curriculum that teachers should be able to develop learning strategies with the PBL approach ranging from design learning process, to teach students so they can solve the problems. This capability is important to be cultivated in problem based learning so it will emerge capability of creative thinking and creative problemsolving. Creative problem-solving orientation will stimulate creative thinking process to solve other problems or encourage other students with the same mindset [4].

Past research showed the effectiveness of PBL approach in some cases, such as: promoting high order thinking, knowledge construction, collaborative learning, and independent learning [5]. When PBL associated with requirement skills for $21 \mathrm{st}$ century, it can contribute the emergence of important skills, which are critical thinking and problem solving [6].

The aim of this research is to develop an early model of PBL integrated toward the enhancement of soft skills of high order thinking skills for vocational students of patisserie expertise. Scopes of this research are 1) analyzing the curriculum of patisserie course on food engineering education study program, 2) finding soft skills required in patisserie industries. This information is important to put the learning 
stages with integrated PBL approach so it can describe the role of lecturer and student during learning.

\section{METHOD}

This research was a set developing model based on Problem Based Learning (PBL) integrated to enhance of integrated soft skills of high order thinking for vocational student in patisserie expertise. This research used $R \& D$ approach in the field of education [7]. There were 3 stages, such as: 1) preliminary study, 2) development of model, and 3 ) testing the model. This paper was the result of preliminary study phase, as an initial activity to find out patisserie learning that has been carried by department food and fashion education, engineering faculty, Yogyakarta State University (PTBB-FT UNY). In this phase, researchers analyzed learning in patisserie course in PTBB-FT UNY. Furthermore, the research team identified and defined high-level soft skills, through literature study, and Focus Group Discussion (FGD). FGD involve patisserie learning experts, practitioners of bakery entrepreneur, and alumni who own bakery that totaled 10 persons. It was guided by an open instrument developed by researchers. Through FGD, researchers can collect data quickly; gather information about mastery of essential soft skills, including soft skills of high order thinking. The data are semi-structured, in the form of conclusion derived from active participation during discussion. Hereafter, data were analyzed and grouped according to the guidelines that have been made by researchers. Through this study, researchers can determine the pattern of PBL that should be applied in order to give effective results to develop soft skills of high order thinking.

\section{RESULT AND DISCUSSION}

\section{A. Patisserie curriculum analysis in Program of Food Engineering Education FT UNY}

Patisserie course held through 4 courses: 1) patisserie I, giving learning experiences about making cakes, cookies, and quick bread, 2) patisserie II, giving learning experiences about making yeast product and pastry, 3) bakery product, giving experiences about development of products based on patisserie I and II, 4) patisserie business management, giving experiences how to manage patisserie business involving diverse consumers.

Students get variety of learning experiences through those courses. Expectation at the end of learning, students gain competencies equal to level $6 \mathrm{KKNI}$ that adjusted to patisserie field [8][9], such as: 1) capability to apply patisserie expertise and utilize science, technology, and/or art in patisserie while solves the problem and capability to adapt with work situation, 2) mastery the theoretical concept of patisserie in general and in specific deeply, as well as capability to formulate the procedural problem solving, 3) capability to make appropriate decisions based on the analysis of information and data, and capability to provide guidance in selecting alternative solutions related to patisserie while work independently and in group, 4) responsibility for own work and can held accountable for the achievement of organization.

By analyzing the syllabus of four course patisserie, [4] were found primary matters should be comprehended by graduates as a form of mastery soft skills and hard skills, as follow in figure 1[4]:

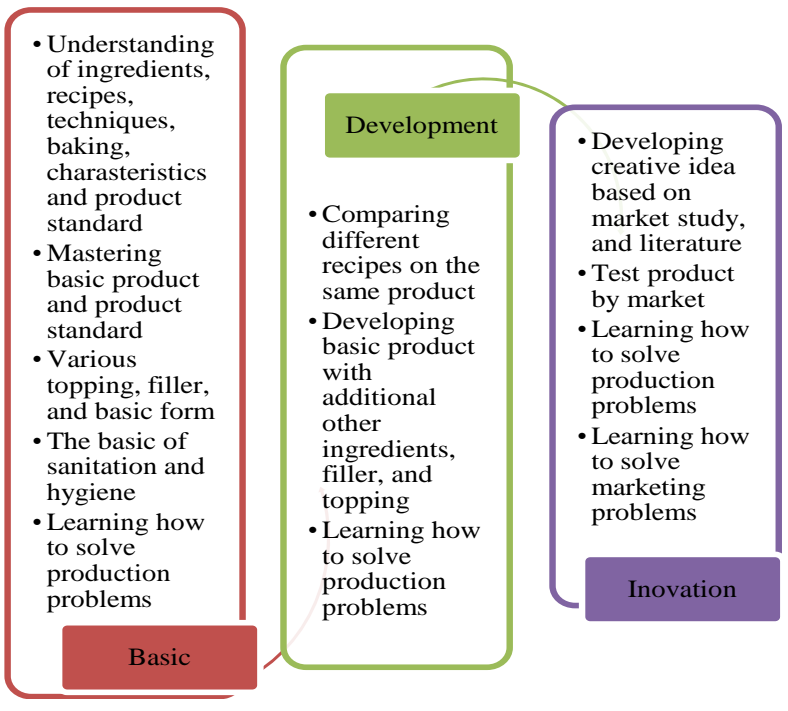

Fig. 1. Mechanism of Patisserie Learning [7]

Through the learning mechanism, students will learn:

1) Basic Capabilities: The basic capabilities support mastery KKNI about: mastering the theoretical concept of patisserie in general and in specific deeply as well as capability to formulate the procedural problem solving.

2) Capabilities to Develop Products: This capability is in line with the demands of KKNI, namely: responsibility for own work and can held accountable for the achievement of organization.

3) Capabilities to Innovate Products: Capabilities to innovate patisserie product support competence (KKNI), such as capability to apply patisserie expertise and utilize science, technology, and/or art in patisserie while solves the problem and capability to adapt with work situation.

Patisserie learning experiences should give space emergence of capabilities to create new products as innovation result independently. This capability is very important as a part to motivate the students to do better, or as a form of selfaccountability. This pattern applied in line with Nealy's research [10] about the integration of soft skills through active learning. Nealy [10] found that active learning has grown soft skills and other skills necessary to improve work performance in the era of the $21^{\text {st }}$ century. This research also gives reinforcement that integrated soft skills learning should be supported by learning experiences that involve physical, mental, student psyche, and independent learning. Therefore, soft skills should be integrated to learning of patisserie. In line with that, Robles [11] found 10 necessary soft skills that should be integrated in curriculum, include: integrity, communication, courtesy, responsibility, interpersonal skills, professionalism, positive attitude, teamwork skills, flexibility, and work ethic. These soft skills are necessary to improve workforce capability. It added that soft skills = interpersonal (people) skills + personal (career) attributes. 


\section{B. The discovery of the necessary soft skills in bakery industries}

Soft skills are required in bakery industries. One definition of soft skills is a person's ability to motivate himself, use initiative, have an understanding about what he need to be done and well, useful to overcome small problems that arise suddenly and persistence when the problem still unsolved [12]. Adequate mastery of soft skills will maintain the quality of workforce in bakery. The element of soft skill will determine attainment and functionalization of cognitive and psychomotor [13]. Accordingly, through FGD involving 10 bakery owners and workers, [4] found 8 important soft skills that should be possessed by workforce in bakery industry, such as:

- Commitment: the ability to keep promises on production quality, Standard Operation Procedure (SOP), and the company slogan.

- Responsibility: workforce is consistent with his work and keeps with his standard work.

- Discipline: workforce obey and adhere to standard working procedures or SOP, and always consistent.

- Striving to achieve success: workforce is consistent to keep quality of work, manage work with satisfactory standard, and orientate to success.

- Learning all the time: workforce doesn't stop learn, always consistent in learning, use work experience as learning tool, and doesn't repeat same mistakes.

- Creativity: workforce develop creative ideas, use knowledge and skills to make product which appealing and attractive.

- Strategic thinking: workforce consistently makes priorities based on the job, and organizes work effectively, efficiently, and systematically.

- Problem solving: workforce tries to find problems, find solutions, and test them. He use data, information, and fact to construct knowledge and used it to solve the problem.

Each soft skill is described in terms of work activities as follows [4]:

\section{1) Commitment}

a) Ability to maintain quality of ingredients all the time.

b) Ability to maintain product all the time by using standard recipe.

c) Ability to fulfill promises to the consumers.

d) Ability to maintain the company slogan.

2) Responsibility results.

a) Ability to demonstrate performance on standardized

b) Ability to work in accordance with work procedures.

c) Ability to work with standard of personal hygiene and work environment.

d) Ability to meet the needs and desires of consumers e) Responsiblity for the damage/ fault in production.

\section{3) Discipline}

a) Ability to work on time.

b) Adherence to recipe, don't change the ingredients or measure.

c) Adherence to work instruction.

4) Striving to achieve success

a) Trying to do the best.

b) Working earnestly.

c) Ability to maintain quality of the products so the business thrive.

d) Taking advantage of business opportunities.

e) Using internet to promote.

f) Finding and maintaining the character product which needed by consumers.

g) Expanding the marketing network.

\section{5) Learning all the time}

a) Ability to learn from failure.

b) Using social media to find public response about his product as a part of learning.

c) Ability to use work experiences as part of selfimprovement.

d) Joining courses to produce a particular product or which is popular with public.

e) Ability to use a variety of learning resources for selfimprovement.

\section{6) Creativity}

a) Ability to develop innovative product to cope with saturation of production by combining ingredients, filler, shape, and decoration. analysis.

b) Ability to find creative ideas based on market

c) Ability to develop product desired by consumer.

7) Strategic thinking

a) Ability to create working order efficiently and effectively.

b) Ability to calculate time of production. labor.

c) Ability to share the work appropriately by optimizing

d) Ability to maintain teamwork.

\section{8) Problem solving}

a) Ability to analyze production error and find the source of problem.

b) Ability to set standard of work in every step of production to maintain the quality.

c) Testing the product any time in order to remain popular with consumers.

d) Ability to create different prices for the same product with different sizes.

e) Analyzing market and finding differences in the same product at different prices, which used for product analysis. 
f) Trying to keep the customer from switching.

g) Ability to listen the needs and desires of the consumers and fulfill them.

h) Addressing complaints of consumer by improved products or services. solution.

i) Analyzing employee problems and finding the

j) Utilizing guidance for optimizing performance.

k) Optimizing teamwork and maintaining a solid team.

The assessment found five soft skills that require highorder thinking, such as: striving to achieve success, learning all the time, creativity, thinking strategies, and problem solving. Furthermore, the five soft skills will be developed in high-order soft skill integrated based on problem in vocational students. Learning of soft skill through integrated PBL approach has the advantage to overcome the problem. Integrated of learning of soft skills is proper with problembased learning [14].

Several studies support integrated soft skill problem-based learning: Walters and Sirotiak [15] research the effect of problem based learning on soft skills (leadership and integrated communication). They found this learning can improve the ability to set goals, and identify and organize best effort to achieve the goals. It is recommended that PBL is suitable for learning of technical and non-technical. Woodward, Sendal, and Ceccucci [16] research about comparing integrated soft skills through project-based learning with curriculum based on information. They found capability to work getting better when there is integration between technical skills and soft skills. Similarly, research on the advantage of integrated of soft skills learning found the development of soft skills through guiding and growing [17]. They found integration soft skills into curriculum give variation on learning experiences, especially when interacting with students [17]. Learning activities that created by lecturer assist students in developing and constructing soft skills independently.

Integrated learning for high-order thinking of soft skills intended to address various problems related to the result of TIMSS study. Indonesian students are ranked very low in ability, namely: 1) to understand complex information, 2) theory, analysis, and solve problem, 3) to use of tools, procedures, and solve problem, 4) conduct investigation [18].

\section{The Design Learning Model of PBL Integrated Toward Enhancement Soft Skills of High Order Thinking for Vocational Students in Patisserie Expertise}

Learning of high-order thinking soft skills will work well when learning experiences created by the lecturer. The learning experiences will assist self-supported for students, sharpen problem-solving skills, critical thinking, and challenge to improve themselves. These capabilities used to self-improvement related to work demands. Patisserie learning requires a lot of challenges, related to product development relatively continue evolving. Maintain products in order to survive and innovative requires struggle. Students should be sharpened with challenges to solve the problem both product and innovations, which have effects on improving soft skills of high-order thinking. Students should be introduced to data, information, facts, and their utilization to construct knowledge and apply it to solve the problem. Students will be familiar with work competence demand, because the problem that developed cannot be separated from its context. Integrated high-order thinking of soft skills encourage students elaborate all efforts of mastering skills to manage self-learning, remembering, and thinking. In addition, those soft skills, encourage students to learn particular ways that different with what is mastered, learn techniques of thinking for analyzing the problems, and solving the problems [2]. This way, students are able to solve the problem thoroughly, utilize knowledge that has been mastered in new situations, and develop problem-solving skills for exploring or developing creativity. This integration of developed model will be selected from the curriculum integration model developed by Fogarty[19].

PBL integrated design inspired Barret [20]: 1) read problems/ trigger that intend to understand keywords, terms or other important things in the trigger; 2) formulate the core problem or challenge as the initial idea in understanding the problem; 3) brainstorm by proposing idea or explanation mutually, as a form of answers or examples that are already known; 4) do discussion and integrating some opinions on the problems, also conclude agreement on the key themes; 5) formulate the main problems to be studied further; 6) study independently and freely by staying in the corridor of theme that has been set, and combine intent of the problem critically; 7) conduct debate professionally by using some information, literature, or the experiences of experts, and conclude the learning outcomes that associated with the problems and professional practical needs.

Lecturer can develop integrated PBL syntax. The syntax contain essential elements or phases, in the form of activities that are arranged in order [21]. Some important points when arrange syntax are:

1) PBL develop culture of inquiry,

2) Each student in a work team should describe problems, find a way or keywords for every problem,

3) Work with work team, and work hard to solve the problem,

4) Emphasis on self-regulated learning (Jordan dan Porath, 2006:8), such as: strategy of effective learning, independent reflection about what has been thought and learned (metacognition), motivation, and engagement with school works.

According to those points, syntax model integrated PBL uses 6 stages:

First, lecturers provide problems, as a challenge, that developed based on study of curriculum and work context. The problem that should be solved by students, designed as 3 complex problems and some simple problems. Next, the lecturer explains 8 soft skills of high order thinking along their behavior that will be cultivated during the learning. Students make study contract that state they will actively involve in learning based on integrated PBL. In addition, students must describe activities for each soft skills of high order thinking associated with patisserie learning context by PBL approach. 
Hence, each student ready to learn based on integrated PBL design.

Second, through brainstorming scenario, students describe problems. It means students find and describe problems that related to context, study fact or evidences in research, readings or other information.

Third, Students manage work teams, especially establish effective communication, collaboration, and formulate the inquiry procedures. Members should have effective role to support teams' performance.

Fourth, through effective teamwork, students find problem themes, make clarification, find key words, construct concept and problem map, develop questions and possible alternative solutions. The work teams must be well-organized, and maintained.

Fifth, students should manage information and evidence. Furthermore, they are required to deduce information as much as possible from various resources, and maintain their motivation and attention to solve the problems. They are required to explore, and realize that what has been learned has relevance with knowledge; even it was already known or new. Students should be able to reflect independently what has been thought and learned. They are trained to think critically, try to achieve success, have creativity and innovation, and also learn from mistakes.

Sixth, students test solutions. They work through observation, training, and testing. They verify with objects or work condition, and problems in work situation. They should be able to show better performance of integrated soft skills of high order thinking.

Based on those stages, researchers develop scenario of learning activities stages presented in following table:

TABLE 1. PATISSERIE LEARNING SCENARION BASED ON INTEGRATED PBL

\begin{tabular}{|c|c|c|c|c|}
\hline \multirow{2}{*}{ No } & \multirow{2}{*}{ Stage } & \multirow{2}{*}{ Strategies } & \multicolumn{2}{|c|}{ Roles } \\
\hline & & & Lecturer & Student \\
\hline 1. & $\begin{array}{l}\text { The design of } \\
\text { learning } \\
\text { integrated PBL } \\
\text { based on } \\
\text { curriculum } \\
\text { studies as } \\
\text { beginning } \\
\text { activity }\end{array}$ & $\begin{array}{l}\text { Specify the } \\
\text { problems or } \\
\text { challenges; } \\
\text { Determine } \\
\text { work activites } \\
\text { for each soft } \\
\text { skills behavior } \\
\text { based on } \\
\text { integrated } \\
\text { PBL; } \\
\text { Create study } \\
\text { environment } \\
\text { as form of } \\
\text { motivation; } \\
\text { Connect } \\
\text { problems with } \\
\text { work } \\
\text { environment } \\
\text { needs }\end{array}$ & $\begin{array}{l}\text { Review } \\
\text { curriculum } \\
\text { and work } \\
\text { context; } \\
\text { Formulate } \\
\text { behavior of } \\
\text { soft skills of } \\
\text { high order } \\
\text { thinking; } \\
\text { Understand } \\
\text { the problems } \\
\text { related to } \\
\text { learn and } \\
\text { work context; }\end{array}$ & $\begin{array}{l}\text { Assess soft } \\
\text { skill of high } \\
\text { order thinking } \\
\text { and behavior, } \\
\text { analyze work } \\
\text { activites for } \\
\text { each } \\
\text { behavior; } \\
\text { Create learn } \\
\text { contract; } \\
\text { Describe the } \\
\text { problems; } \\
\text { Ask question } \\
\text { to understand } \\
\text { the problems; } \\
\text { Assess } \\
\text { problems } \\
\text { associated } \\
\text { with } \\
\text { empirical } \\
\text { evidence; }\end{array}$ \\
\hline
\end{tabular}

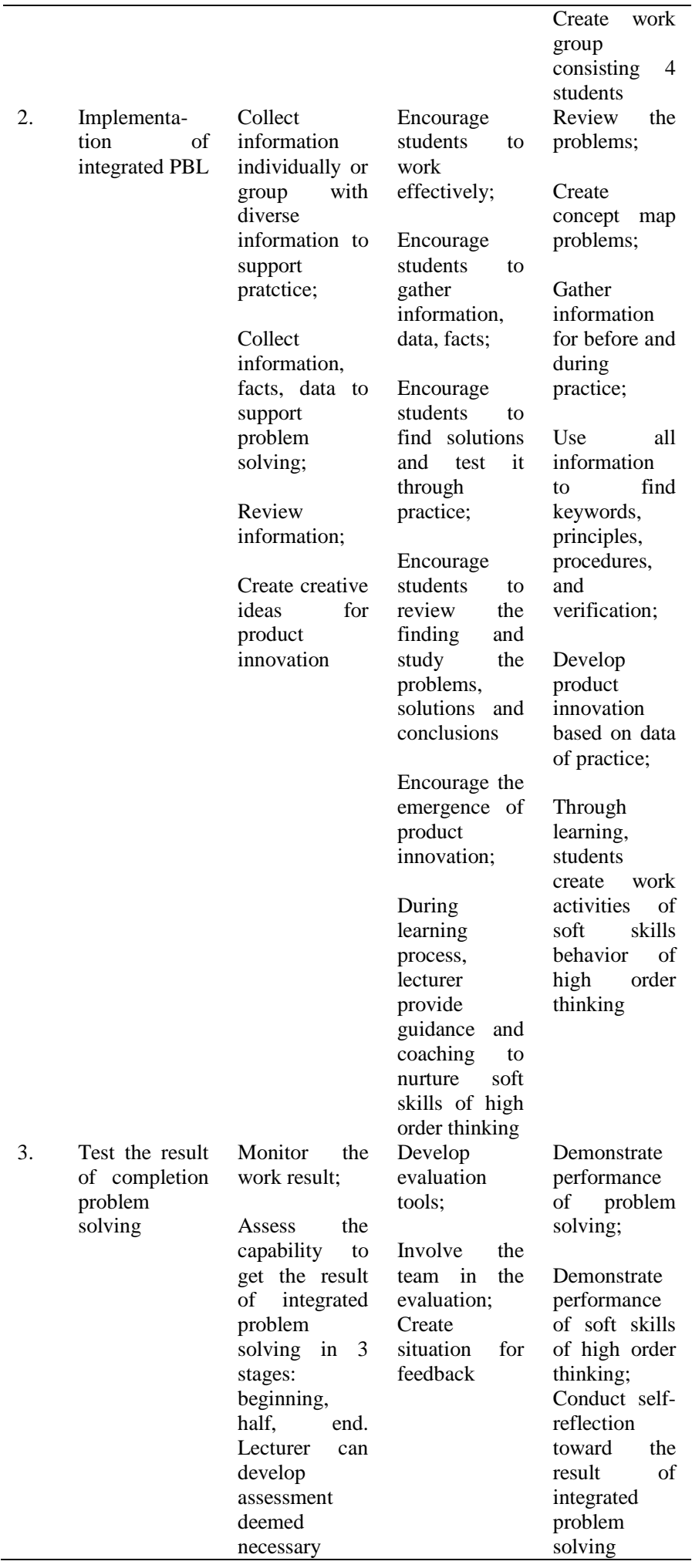

\section{CONCLUSION}

Learning model design of PBL integrated is patisserie learning model designed to nurture soft skills of high order thinking that integrated with hard skills of patisserie. Learning mechanism follows integrated PBL approach that 
demonstrated in learning syntax. Integrated PBL approach allows students holistically construct knowledge, attitudes, values, and skills. They will be more delicate to the demand of work. Mastery of integrated problem solving will give positive impact for the emergence of students' ability to solve the problem thoroughly, utilize knowledge that has been mastered in new situations, and develop problem-solving skills for exploring or developing creativity. Vocational students of Food Engineering Education, FT UNY, are prospective teachers. Hence, mastery of integrated PBL will give positive values when students have become teacher who has to teach curriculum 2013. Learning that designed in curriculum 2013 emphasize PBL approach, project-based learning, and inquiry.

\section{REFERENCES}

[1] W. G. Mitchell, "Essential Soft Skills for Success in the Twenty-First Century Workforce Perceived by Business Educators". [Online] Available etd.auburn.edu/etd/bitstream/handle/10415/1441/mitchellgeana_57/pdf? sequence, 2008.

[2] M. R. Gagne, The Conditions of Learning. New York: Holt Rinehart and Winston, 1977.

[3] K. A. Badeau, "Problem-Based Learning an Educational Method for Nurses in Clinical Practice". Journal For Nurses in Staff Development, Vol 6, 2010.

[4] S. Hamidah, Widjiningsih, Yuriani, and S. Palupi, "Effektifitas model pembelajaran berbasis problem-based-learning terintegrasi terhadap peningkatan soft skills berpikir tingkat tinggi bagi mahasiswa vokasi keahlian patiseri", Unpubilshed, 2015.

[5] O. S. Tan, Problem-based learning and creativity. Singapore: Cengage Learning Asia Pte Ltd, 2009.

[6] B. Trilling, and C. Fadel, 21st Century Skills-Learning for life in our times. San Fransisco: Jossey-Bass, 2009.

[7] R. W. Borg, and D. M. Gall, D.M., Educational research. New York: Logman inc, 1560 Broadway, 1983.

[8] Kerangka Kualifikasi Nasional Indonesia Nomer 8 Tahun 2012. Jakarta: Peraturan Presiden Republik Indonesia

[9] Standar Nasional Pendidikan Tinggi Nomor 49 Tahun 2014. Jakarta : Peraturan Menteri Pendidikan Dan Kebudayaan Republik Inidonesia

[10] C. Nealy, "Integrating Soft Skills Through Active Learning In The Management Classroom". Journal of Collage teaching \& learning, Vol 2, pp. 1-5, 2005.

[11] M. M. Robles, "Executive Perceptions of the Top 10 Soft Skills Needed in Today's Workplace”. [Online] Available http://bcq.sagepub.com, 2012.

[12] I. Grugulis, Skill, Training. and human resource development. Critical texts. England: Palgrave Macmilan.

[13] Dikti, Rencana Strategis 2010-2014. Direktorat Jendral Pendidikan Tinggi. Jakarta: Kementerian Pendidikan Kebudayaan, 2010.

[14] Precision Consultancy, Graduate employability skills prepared for the business, industry and higher education collaboration council. Barton, ACT 2600: Commonwealth of Australia, 2007.

[15] R. C. Walters, and T. Sirotiak, "Assessing the effect of project based learning on leadership abilities and communication skills".[Online] Available http://ascpro.ascweb.org/chair/paper/CERT301002011.pdf, 2011.

[16] B. Woodward, P. Sendall, and W. Ceccuci. Integreting soft skills competencies through project-based learning across the information system curriculum. Washington DC: Proc ISECON, 2009.

[17] Bergh, et al., "Medical Students Perceptions of their Development of Soft Skills. Part II: The Development of Soft Skills Through Guiding and Growing”. [Online] Available http://www.sofpj.co.za/index.php/safpj/article/viewfile/661/575, 2006.

[18] Dokumen Kurikulum 2013. Jakarta: Kementerian Pendidikan dan Kebudayaan Desember, 2012.
[19] R. Fogatry, The Mindful School: How to Integrate the Curricula. Illinois: IRI/Skylight Publishing, Inc., 1991.

[20] T. Barrett. Introduction to Enquiry and Problem-based Learning (T Barrett and D. Cashman, Eds.). Dublin: University College Dublin Teaching and Learning, Woodview House, 2010.

[21] B. Joyce, M. Weil, B. Shower, Models of Teaching. Boston: York Production Service, 1992. 